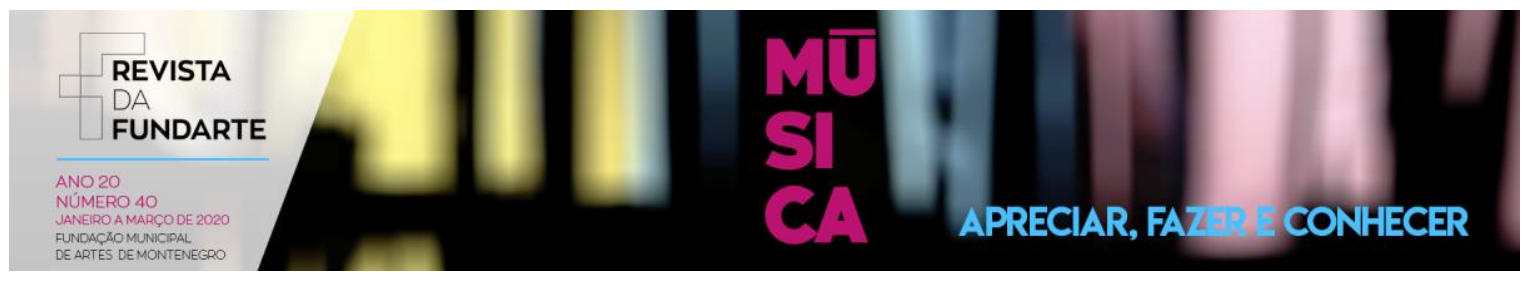

\title{
MÚSICA NO RIO GRANDE DO SUL: CONHECENDO AS ORIGENS E ALGUNS GÊNEROS MUSICAIS
}

Cristina Rolim Wolffenbüttel

DOI: http://dx.doi.org/10.19179/2F2319-0868/2F757 


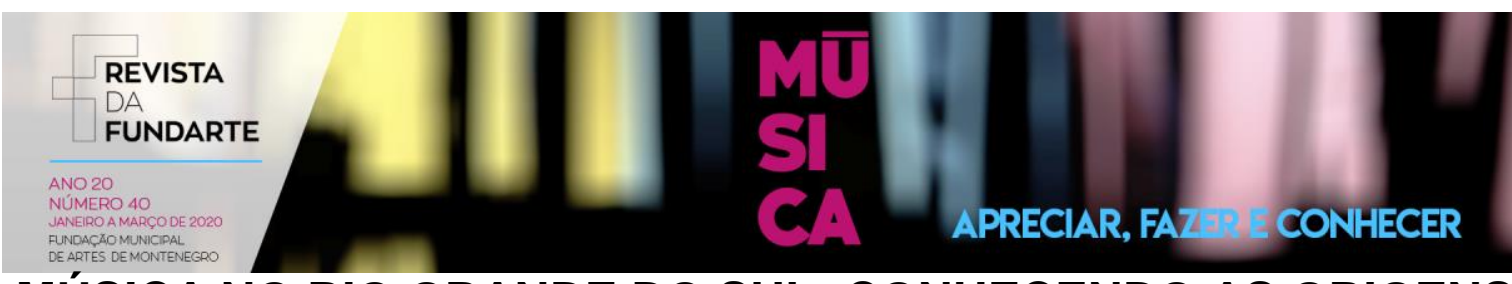

MÚSICA NO RIO GRANDE DO SUL: CONHECENDO AS ORIGENS E ALGUNS GÊNEROS MUSICAIS

Cristina Rolim Wolffenbüttel ${ }^{1}$

Resumo: Este ensaio apresenta um panorama da música no Rio Grande do Sul, optando pela abordagem acerca de alguns gêneros musicais que chegaram ao Brasil e, posteriormente, no Estado sulino, incluindo a valsa, polca, xote e rancheira. Após, é apresentado um panorama geral do RS, por meio da apresentação das heranças culturais da música gaúcha e das características dos gêneros musicais do RS. Por fim, são explicitados os gêneros musicais vaneira, o vaneirão, o bugio e a trova, particularmente na trova em Mi Maior de Gavetão, de Martelo e por Milonga, procurando apresentar conclusões na perspectiva na importância do conhecimento sobre a música no RS, suas origens e características.

Palavras-Chave: Música; Rio Grande do Sul; Cultura Gaúcha.

\section{MUSIC IN RIO GRANDE DO SUL: KNOWING THE ORIGINS AND SOME MUSICAL GENRES}

Abstract: This essay presents an overview of music in Rio Grande do Sul, choosing to approach some musical genres that arrived in Brazil and, later, in the southern state, including waltz, polka, xote and rancheira. Afterwards, an overview of Rio Grande do Sul is presented, through the analysis of the cultural inheritances of southern music and the characteristics of the musical genres of the state. Finally, the musical genres vaneira, vaneirão, bugio and trova are made explicit, especially Mi Maior by Gavetão, Martelo and Milonga, seeking to present conclusions from the perspective of the importance of knowledge about music in Rio Grande do Sul, its origins and characteristics.

Keywords: Music; Rio Grande do Sul; Gaucho Culture.

\section{Introdução}

A música popular no Rio Grande do Sul (RS) é o resultado de uma mescla de influências das várias etnias que se dirigiram para o estado sulino em busca do sustento e da sobrevivência. Muitos foram os povos que vieram para o RS. Neste artigo

\footnotetext{
${ }^{1}$ Cristina Rolim Wolffenbüttel: Pós-Doutora, Doutora e Mestre em Educação Musical pela Universidade Federal do Rio Grande do Sul. Especialista em Informática na Educação - Ênfase em Instrumentação, pela Pontifícia Universidade Católica do Rio Grande do Sul. Licenciada em Música pela Universidade Federal do Rio Grande do Sul. Coordenadora do curso de Especialização em Educação Musical na Universidade Estadual do Rio Grande do Sul, Unidade de Montenegro. Professora do Programa de Pós-Graduação em Educação da Universidade Estadual do Rio Grande do Sul. Orientadora de bolsistas de iniciação científica e extensão em Música e Artes, da FAPERGS, CNPq e UERGS. Coordenadora do Grupo de Pesquisa "Educação Musical: diferentes tempos e espaços" (CNPq/PPGED/Uergs) e do Grupo de Pesquisa "Arte: criação, interdisciplinaridade e educação". Coordenadora da Biblioteca e do Núcleo de Culturas, Ciências e Diversidades da Secretaria Municipal de Educação de Porto Alegre. Diretora Regional Sul da Associação Brasileira de Educação Musical. Integrante da Comissão Gaúcha de Folclore e da Fundação Santos Herrmann.
}

WOLFFENBÜTTEL, Cristina Rolim. Música no Rio Grande do Sul: conhecendo as origens e alguns gêneros musicais. Revista da FUNDARTE. Montenegro, p.254-277, ano 20, no 40, janeiro/março de 2020. Disponível em: http://.seer.fundarte.rs.gov.br/index.php/RevistadaFundarte/index> 31 de março de 2020. 
tratar-se-á de alguns dos gêneros musicais trazidos pelos europeus, como a valsa, a polca, o xote e a rancheira, que trouxeram os hábitos tão peculiares de sua terra natal.

Posteriormente, de acordo com o convívio dos imigrantes com os costumes gaúchos, estes gêneros musicais foram se aculturando ${ }^{1}$, surgindo outros, dentre os quais podem ser mencionados a vaneira, o vaneirão, o bugio e a trova, esta última em suas diversas modalidades, como a em Mi Maior de Gavetão, a de Martelo e a por Milonga. Estes gêneros musicais também são foco deste estudo.

Para o entendimento de cada um desses gêneros musicais, é fundamental o conhecimento de suas origens, inserindo-as no contexto histórico da formação do Estado.

\section{Valsa, Polca, Xote e Rancheira: conhecendo algumas particularidades}

Gênero de dança ou peça de concerto originada das danças rústicas alpinas (da Áustria), principalmente o ländler (BANGEL, 1989), a valsa chegou ao Brasil por volta de 1830, devido à fama das valsas vienenses de Johann Strauss. Diversos compositores eruditos europeus dedicaram-se a este gênero musical, podendo ser mencionados Haydn, Mozart, Beethoven e Schumann, entre outros.

As primeiras notícias de composições de valsas, no Brasil, estão ligadas aos nomes do príncipe Dom Pedro I e Sigismund Neukomm (KIEFER, 1983). Sendo muito cultivada neste país, as valsas apareceram tanto em nível erudito, quanto popular, tendo surgido um grande número de publicações das partituras deste gênero musical. Conforme Bruno Kiefer (1983), muitas destas publicações foram impressas no Brasil. Havia valsas de compositores europeus, de estrangeiros residentes no Brasil, além de brasileiros. Dentre estes últimos, salientam-se Henrique Braga, Carlos Gomes, Francisco II Gonzaga, Ernesto Nazareth e Alberto Nepomuceno.

Segundo Cascudo (1984, p. 782), a valsa "veio a divulgar-se no Brasil durante fins do I império o período regencial, justamente quando Paris inteiro a consagrava,

\footnotetext{
1 Aculturação: um dos processos que ocorre na dinâmica do folclore, quando dois grupos culturais distintos entram em contato, mesclando-se, surgindo um novo padrão cultural. Também pode ser denominado de transculturação.

WOLFFENBÜTTEL, Cristina Rolim. Música no Rio Grande do Sul: conhecendo as origens e alguns gêneros musicais. Revista da FUNDARTE. Montenegro, p.254-277, ano 20, no 40, janeiro/março de 2020. Disponível em: http://.seer.fundarte.rs.gov.br/index.php/RevistadaFundarte/index> 31 de março de 2020.
} 
1830 e seguintes". Em relação às características musicais especificas, a principal é seu compasso, um ternário simples, cuja acentuação recai sobre o primeiro tempo. $\mathrm{O}$ andamento pode ser bastante diversificado. Há valsas mais rápidas e outras mais lentas.

Ao integrar o repertório popular dos demais estados, a valsa adquiriu aspectos variados, mudando de região para região. As valsas do $\mathrm{RS}$ apresentam-se um pouco mais marcadas que as europeias, talvez devido ao fato de as danças gaúchas serem mais acentuadas. Ainda hoje, nos ranchos gaúchos, em bailes de fandango, a valsa aparece com destaque, pois é uma dança de grande aceitação popular. Ela realmente vem a enfeitar os salões, com as apresentações de várias de suas figurações coreográficas, desenvolvidas pelos “amantes” deste gênero.

A polca, outro gênero musical importante para as origens da música sul-riograndense, ao entrar no Brasil, em 1844, teve suas primeiras apresentações nos teatros do Rio de Janeiro (KIEFER, 1983). Nessas mostras, o gênero musical difundiuse com grande rapidez para os demais Estados, tornando-se uma dança que não podia deixar aparecer, como diziam os gaúchos, antigamente, em qualquer baile "que se prestasse".

Dança em compasso binário simples e bastante viva, a polca tem sua origem ligada ao século XIX, na Boêmia, passando para a França e espalhando-se para os demais países, inclusive o Brasil. Outrora, à semelhança da valsa, havia uma enorme quantidade de partituras de polcas impressas no Brasil, tanto de compositores brasileiros, quanto de estrangeiros (KIEFER, 1983).

A polca europeia apresenta algumas características diferentes daquela que veio a ser conhecida no Brasil. Enquanto a polca de origem europeia possui um acompanhamento rítmico mais marcado (colcheias e semínima), a brasileira pode apresentar notas pontuadas (colcheia pontuada/semicolcheia/colcheia/colcheia). No entanto, esta célula rítmica pontuada não é muito frequente. Seu aparecimento pode ser devido às confluências ocorridas entre a polca e outros gêneros musicais, tais como o lundu e a habanera, nos quais estes ritmos são marcas inconfundíveis. Conforme explica Kiefer (1983, p. 19) "[...] polcas que podemos situar na época de 1870 sugerem gêneros musicais. Revista da FUNDARTE. Montenegro, p.254-277, ano 20, no 40, janeiro/março de 2020. Disponível em: http://.seer.fundarte.rs.gov.br/index.php/RevistadaFundarte/index> 31 de março de 2020. 
que nesta época deve ter começado a fusão entre os ritmos da polca européia e da habanera... onde o ritmo de acompanhamento da habanera é flagrante... Polca Lundu significa aqui, visivelmente: lundu na parte melódica, habanera no acompanhamento".

No entanto, no Brasil e, particularmente no RS, as características da polca podem ser resumidas na utilização do compasso binário simples (2/4), possuindo 0 andamento em torno de um Allegretto. Existem polcas ternárias, porém são difíceis de serem encontradas. O ritmo básico de acompanhamento pode ser exemplificado por: colcheia/colcheia/colcheia/semicolcheia/semicolcheia ou quatro colcheias seguidas.

Mais remotamente, em muitas localidades do RS, a polca era chamada de "limpa-banco", pois, quando executada, ninguém ficava sentado. Isto demonstra a alegria contagiante que envolve este gênero de música. Bangel (1989), ao tratar da polca limpa banco, explica que "quando executada, ninguém fica sentado, daí, então, limpa-banco" (p. 47). Atualmente, podem ser observadas polcas com diferentes indicações de caráter, demonstrando a ocorrência de alguns hibridismos neste gênero musical. Não raro encontramos nomes como "polca paraguaia", "polca missioneira" e polca "mancada", entre outras.

Originado da schottisch europeia (BANGEL, 1989), a dança do xote (com " $x$ ", na versão em português) entrou no Brasil por volta de 1850. Trata-se de uma dança derivada do que os franceses imaginavam ser uma dança escocesa, pois schottisch, em alemão, significa escocesa. Ao chegar ao Brasil, o xote estabeleceu-se no Rio de Janeiro. Devido às suas características de alegria e descontração, a dança se popularizou, passando a integrar conjuntos instrumentais pequenos, como os "chorões". Aos poucos, com a inclusão dos versos e do acompanhamento do violão, o xote converteu-se em modinha.

Dentre suas características musicais, o xote apresenta semelhança com a polca. O compasso pode ser o binário ou quaternário, e o andamento, rápido, de caráter alegre. No RS, o xote é dançado ao som do acordeão, e isto se deve ao fato de que a aceitação deste gênero musical "coincidiu com a difusão da gaita" (MARCONDES, 1977, p. 815). Bangel (1989) explica algumas características musicais do xote: 


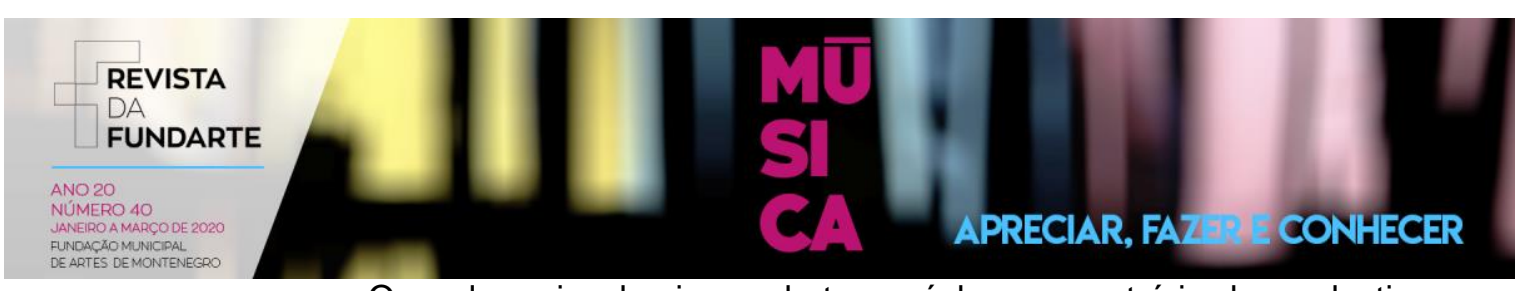

O modo maior domina o chotes gaúcho, ao contrário do nordestino, em que o modo menor aparece com muita frequência, além da elevação do $4^{\circ}$ [grau] e abaixamento do $7^{\circ}$ grau, que personalizam o estilo nordestino. O chotes binário, tanto no compasso, como na forma. (BANGEL, 1989, p. 41).

Há, basicamente, quatro tipos de xote na região sulina: O "carreirinho", o "de se largar", o "afigurado" e o "solado". No RS há, principalmente, dois xotes muito conhecidos, que são "Laranjeira" e "Carreirinho" (também referido como "Carreirinha" ou "De Carreirinha"), ambos já folclorizados. Uma boa escuta destes gêneros pode ser realizada por meio do acesso a alguns links, no Youtube. O xote "Laranjeira" tem belas interpretações, sendo uma delas com ledo Silva², e outra com o grupo musical Os Mirins $^{3}$, apenas para mencionar alguns exemplos. Dentre tantos artistas que gravaram essa música, o xote "Carreirinha" pode ser apreciado na voz do inesquecível Paixão Côrtes ${ }^{4}$ e do grupo Os Minuanos ${ }^{5}$.

A rancheira, outro gênero musical importante na história da música do $R S$, tem suas origens ligadas à mazurca e à contradança, danças advindas da Europa. Segundo Bangel (1989, p. 38), "é o gênero mais gaúcho dentro da música brasileira, por não se encontrar similar entre outros estados". Erroneamente, muitos pensam que este gênero musical descende da valsa. Isto não procede, na medida em que a mazurca, dança polaca (possivelmente proveniente da Mazovia), do século XVII, da qual descende a rancheira, mesmo tendo o compasso ternário simples, tem sua acentuação no $2^{\circ}$ tempo do compasso. Isto ocorreu devido à popularização da dança, com o seu deslocamento rumo aos ranchos das campanhas. À semelhança da polca e da valsa, o andamento da rancheira é mais movido.

Às vezes, também ocorre uma confusão com outra dança, o terol. Isto não se justifica, na medida em que a rancheira possui o acento métrico no $1^{\circ}$ e $3^{\circ}$ tempos do compasso, diferenciando-se do terol, o qual tem o acento apenas no $3^{\circ}$ tempo.

\footnotetext{
2 ledo Silva-Xote Laranjeira - https://www.youtube.com/watch?v=UvILMSaPjiE.

3 Os Mirins-Xote Laranjeira-1987 - https://www.youtube.com/watch?v=NVNb1tZOpuA.

4 João Carlos D'Ávila Paixão Côrtes (1927-2018), importante personagem na cultura gaúcha, era agrônomo, mas construiu grande carreira como folclorista, compositor, radialista e pesquisador das tradições e cultura gaúcha. Foi, também, autor de uma vasta discografia. https://www.youtube.com/watch?v=Z-axF vHTTo.

5 Os Minuanos - Chotes -(Laranjeira) - Chotes - (Recolhido: Paixão Cortes - Barbosa Lessa) https://www.youtube.com/watch?v=2183JNcOkew.

WOLFFENBÜTTEL, Cristina Rolim. Música no Rio Grande do Sul: conhecendo as origens e alguns gêneros musicais. Revista da FUNDARTE. Montenegro, p.254-277, ano 20, no 40, janeiro/março de 2020. Disponível em: http://.seer.fundarte.rs.gov.br/index.php/RevistadaFundarte/index> 31 de março de 2020.
} 


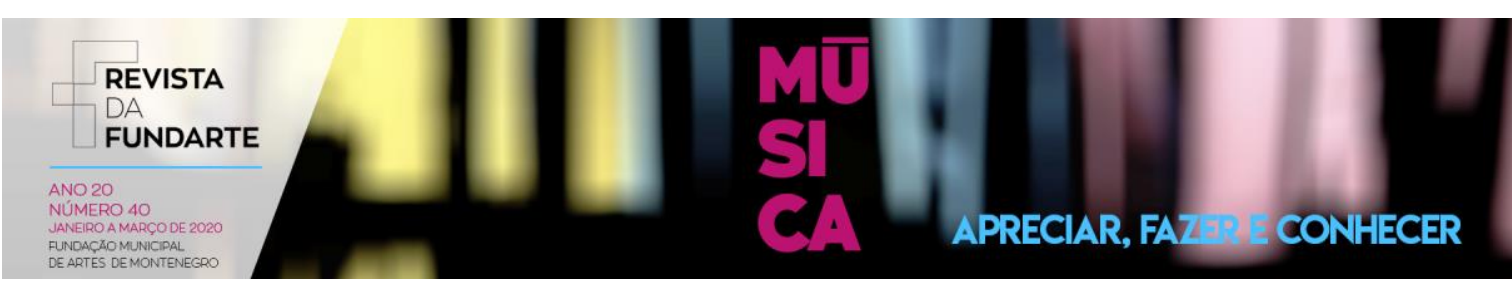

A rancheira mais antiga de que se tem notícia no RS, chamada "pioneira", é o "Mate Amargo". O mesmo que mate-chimarrão, amargo, ou outros termos, esta denominação tem muita ressonância, tanto no RS, quanto nos países da região do Rio da Prata ${ }^{6}$. Sempre a mencionar o companheiro de todas as horas, o gaúcho faz com que o chimarrão figure nas letras das diversas composições. Para a apreciação da rancheira "Mate Amargo" sugere-se a escuta da execução desta música no acordeão de Mary Terezinha7.

Os gêneros musicais abordados neste início são apenas alguns exemplos dos vigentes no RS e que, ainda hoje, têm uma grande aceitação popular. São muito importantes, na medida em que contribuíram e continuam contribuindo para a formação, estruturação e caracterização da música sul-rio-grandense.

\section{Heranças Culturais da Música Gaúcha}

Avançando no estudo das raízes musicais gaúchas, é produtivo analisar alguns outros aspectos das heranças culturais presentes na música, independentemente da origem étnica da comunidade ou região do Estado, as manifestações de cunho festivo são muito interessantes, sendo originadas das várias etnias presentes na colonização.

Nas localidades onde há o predomínio do povo alemão, podem ser presenciadas várias festas, nas quais a música e, em especial, o canto, têm o seu destaque. São manifestações como o Kerb, o Terno de Atiradores, a Festa do Rei do Tiro, a Oktoberfest, a Festa do Colono, entre outras festividades de singular beleza.

Em festas italianas, da mesma maneira, não raro há a inclusão de cantos e músicas, muitas delas para o acompanhamento das "danças dos italianos", famosas por sua descontração e empolgante andamento acelerado. Também, o aspecto

6 O Rio da Prata é um importante rio da América Latina. Localiza-se na divisa entre o Uruguai e a Argentina. É um estuário formado pelo deságue das águas dos rios Paraná e Uruguai no Oceano Atlântico.

${ }^{7}$ Mary Terezinha Cabral Brum, ou Mary Terezinha, nome artístico pelo qual ficou conhecida, é cantora, compositora e acordeonista que ficou muito famosa por fazer dupla com o igualmente famoso Teixeirinha. A gravação do "Mate Amargo" integra o disco Sou Gaúcha, de 1978. https://www.youtube.com/watch?v=3nNHARvDX U.

WOLFFENBÜTTEL, Cristina Rolim. Música no Rio Grande do Sul: conhecendo as origens e alguns gêneros musicais. Revista da FUNDARTE. Montenegro, p.254-277, ano 20, no 40, janeiro/março de 2020. Disponível em: http://.seer.fundarte.rs.gov.br/index.php/RevistadaFundarte/index> 31 de março de 2020. 
marcante da religiosidade cristã (que também aparece nas demais etnias) fez com que diversos cantos fossem propagados através das missas. Nas festas de "Corpus Christi", ou mesmo durante a realização dos Terços Cantados, nos lares católicos, os cânticos religiosos sempre estiveram presentes. No tocante à parte instrumental, a valiosa contribuição deste povo foi a introdução do uso do acordeão, o qual acompanha, até hoje, vários gêneros musicais gaúchos.

Não é necessário um deslocamento rumo à fronteira do Estado, a fim de presenciar fatos de origem portuguesa ou espanhola. De um modo geral, estas tradições regionais estão difundidas por todo o Rio Grande do Sul.

Os portugueses - primeiros a chegarem ao Estado gaúcho, além dos africanos e dos indígenas que já estavam nas terras do pampa - foram de grande importância para a caracterização cultural. Quando de sua chegada, os lusos trouxeram seus usos e costumes de Portugal, os quais foram se espalhando por todo o estado. Devem ser lembradas as Missas do Galo, as Festas de Navegantes, as Festas do Divino Espírito Santo, as Festas Juninas, além dos folguedos populares, como o Terno de Reis e as Cavalhadas. Para o entendimento em torno do que sejam os folguedos populares vale explicar, a partir de alguns estudiosos que se debruçaram nessa investigação.

Também denominados brincadeira, folgança, festa, chegança, essas manifestações eram denominadas por Mário de Andrade como danças dramáticas. Para ele, as manifestações reúnem "[...] não só os bailados que desenvolvem uma ação dramática propriamente dita, como também todos os bailados coletivos que, junto com obedecerem a um tema dado tradicional e caracterizador, respeitam o princípio formal da Suíte, isto é, obra musical constituída pela seriação de várias peças coreográficas. (ANDRADE, 1982, p. 71).

Conforme Marques (1989, p. 17), a "maioria dos ritos tradicionais do Estado procede da pátria portuguesa". Das cantigas de roda e de ninar da região, grande parte veio de Portugal sendo, posteriormente, mescladas com outras, resultando as cantigas que existem até hoje no pampa.

Dentre os espanhóis, que chegaram ao Brasil por volta do final do século XIX e início do século $X X$, e cuja influência na formação étnico-cultural é inegável no RS, WOLFFENBÜTTEL, Cristina Rolim. Música no Rio Grande do Sul: conhecendo as origens e alguns gêneros musicais. Revista da FUNDARTE. Montenegro, p.254-277, ano 20, no 40, janeiro/março de 2020. Disponível em: http://.seer.fundarte.rs.gov.br/index.php/RevistadaFundarte/index> 31 de março de 2020. 
fundamental se faz referir o legado musical relacionado à introdução de instrumentos musicais, tais como o violão e o bombo-leguero ${ }^{8}$. Esses instrumentos, juntamente com o acordeão, caracterizam - e, em algumas localidades, ainda predominam - o timbre da música gaúcha. Mais recentemente, devido à influência da música de outras regiões do Brasil e até do exterior, podem ser encontrados instrumentos musicais como a guitarra elétrica, o teclado, o baixo elétrico, entre outros. A língua espanhola e, por consequência, o linguajar do espanhol (advindo dos países da região do Rio da Prata), com seus termos específicos, encontra-se perpetuada nas canções populares sulinas.

De influência negro-africana podem ser destacados, principalmente os folguedos populares da Congada e do Quicumbi. No instrumental figuram, basicamente, instrumentos de percussão, como o agê, maçaquaias e atabaques. No vocabulário dos cantos gaúchos são escutadas palavras cuja origem africana é marcante. Algumas delas podem ser mencionadas, como cacimba (fonte de água potável), cachaça (bebida alcoólica produzida a partir da fermentação da cana-de-açúcar), mandinga (feitiço), e dois termos diretamente ligados à origem da música popular brasileira: o lundu e o samba (NUNES, 1993).

Da cultura musical indígena, infelizmente, pouco nos restou. Isto é, também, um resultado das atividades desenvolvidas pelas Missões Jesuíticas, na região, por volta do séc. XVI, vindo quase a anular por completo as características culturais destes povos. Laytano (1981, p. 52) esclarece que o "vocabulário gaúcho recebeu do indígena os termos da geografia, flora e fauna, como aconteceu em todo o Brasil". Conforme o autor, o Guarani foi a língua usual das Missões, legando uma série de palavras que, até hoje, são utilizadas, dentre as quais podem ser mencionadas "chiru, biguá, mutuca, coronilha, cuia, tocaio, capincho, pixurum, sanrandi, chipa, sapiranga, baita, itaimbé, Aceguá, Bojuru, atovi, guaxuma, Bagé, etc" (LAYTANO, 1981, p. 52). Salientam-se, todavia, os termos de origem tupi-guarani, como o anu, um pássaro cuja referência aparece em uma dança folclórica gaúcha de mesmo nome; pampa, que é um termo

8 O bombo leguero é um instrumento da família da percussão. Suas origens estão ligadas à Argentina, e seu nome é devido ao fato de este instrumento poder ser escutado a léguas de distância. Daí o termo leguero.

WOLFFENBÜTTEL, Cristina Rolim. Música no Rio Grande do Sul: conhecendo as origens e alguns gêneros musicais. Revista da FUNDARTE. Montenegro, p.254-277, ano 20, no 40, janeiro/março de 2020. Disponível em: http://.seer.fundarte.rs.gov.br/index.php/RevistadaFundarte/index> 31 de março de 2020. 
relativo às planícies da região, cobertas de excelentes pastagens, próprias para a criação de gado. Ainda, outro legado dos índios, e que não pode deixar de ser mencionado, é a maneira amorosa de lidar com as crianças, e perpetuada, principalmente, no modo carinhoso de entoar os cânticos de ninar, quando do embalo das crianças, no colo, a fim de fazê-las adormecerem.

Certamente essas não são as únicas etnias que colaboraram para a estruturação das características da música sulina. Os poloneses, os judeus, os japoneses e os franceses, entre outros, também legaram alguns aspectos de sua cultura, quando vieram povoar estes campos rurais. No entanto, a título de caracterização da música do $\mathrm{RS}$, as principais foram comentadas anteriormente, não invalidando, com certeza, outras abordagens.

Antes de efetivar o aprofundamento dos gêneros musicais da região sul-riograndense, necessário se faz o conhecimento das principais características que deles fazem parte.

\section{Características dos Gêneros Musicais do Rio Grande do Sul}

Sendo a dança - tanto a folclórica quanto a popular, chamada de dança de fandango - muito cultivada na região sulina, normalmente, a música desta região é direcionada à dança. $\mathrm{E}$, dentre as danças de fandango, por exemplo, aparecem a vaneira, o vaneirão, o bugio, o xote, a rancheira, a polca, a valsa, a milonga, e o chamamé, dentre os de maior destaque.

Nos cantos, tradição de há muito tempo atrás, também há um grande número de modalidades de cânticos e modos de cantar. Dos tipos de canções, convém salientar o romance, as décimas, o mais e mais a altura vocal, de acordo com o entusiasmo do cantor. Podem ser encontrados três tipos de desafios, os quais são chamados de Trovas: a Trova em Mi Maior de Gavetão, a Trova de Martelo e a Trova por Milonga.

Todos estes gêneros de música, quer sejam de dança ou não, têm determinados aspectos comuns à maioria das músicas do sul. Normalmente, o modo empregado para as músicas é o modo Maior. Nas tonalidades, muitas vezes o cantor ou trovador WOLFFENBÜTTEL, Cristina Rolim. Música no Rio Grande do Sul: conhecendo as origens e alguns gêneros musicais. Revista da FUNDARTE. Montenegro, p.254-277, ano 20, no 40, janeiro/março de 2020. Disponível em: http://.seer.fundarte.rs.gov.br/index.php/RevistadaFundarte/index> 31 de março de 2020. 
escolhe um tom que the seja mais fácil à entonação. Determinados gaiteiros, ao iniciarem suas trovas, escolhem a tonalidade de Mi Maior, por ser esta, segundo depoimentos dos próprios instrumentistas, mais simples de executar.

Além destes elementos musicais, outros devem ser incluídos nesta análise técnico-musical, tais como a fraseologia, a melodia, a harmonia, o compasso, a forma musical e os instrumentos musicais que fazem parte da música gaúcha.

No que se relaciona à fraseologia musical, que é o estudo acerca da construção do próprio discurso musical, articulações e ligações, a música no sul do Brasil apresenta os inícios de frase, em geral, com anacruse, e as terminações são do tipo masculino (terminação no acento tônico do compasso). Uma exemplificação pode ser a audição de um fragmento inicial da dança "Balaio", recolhida por Paixão Côrtes e Barbosa Lessa, no RS?.

A melodia, conforme Bangel (1989, p. 29), "é simples, intuitiva, construída por graus conjuntos e intervalos harmônicos, usando com frequência a escola descendente". Frequentemente há o emprego da repetição de notas, resultando um caráter discursivo à música, quase recitativo. Não raro ocorrem problemas de prosódia nas canções, quando o acento tônico da palavra não combina com o acento do ritmo musical. É bastante comum a canção, ou mesmo a música instrumental gaúcha, apresentarem nos compassos finais, a terminação no III grau da escala, ao invés de finalizar no I grau. Isso confere um caráter suspensivo à música, parecendo esta não ter acabado. Pode ser muito elucidativo realizar a audição da "Décima do Potro Baio", na voz de Noel Guarany ${ }^{10}$.

A harmonia é outro elemento da música que caracteriza a música no RS. $\mathrm{Na}$ maioria das músicas da localidade predomina o acompanhamento harmônico com as seguintes funções harmônicas: tônica - dominante - subdominante. Normalmente, o modo utilizado é o Maior, mas o menor pode aparecer nas milongas e toadas. Via de

\footnotetext{
9 Um bom exemplo do "Balaio" pode ser apreciado na voz de Inezita Barroso, no disco Danças Gaúchas, de 1961, com arranjo de Hervê Cordovil. https://www.youtube.com/watch?v=q-bgd ZehOo.

10 Décimas são cantos, histórias contadas em forma de verso, com um acompanhamento instrumental, normalmente de acordeão. Noel Borges do Canto Fabrício da Silva, conhecido pelo nome artístico Noel Guarany, foi músico gaúcho, responsável por inúmeras composições, dentre as quais se encontra a "Décima do Potro Baio". https://www.youtube.com/watch?v=UG1gtAjbWro .

WOLFFENBÜTTEL, Cristina Rolim. Música no Rio Grande do Sul: conhecendo as origens e alguns gêneros musicais. Revista da FUNDARTE. Montenegro, p.254-277, ano 20, no 40, janeiro/março de 2020. Disponível em: http://.seer.fundarte.rs.gov.br/index.php/RevistadaFundarte/index> 31 de março de 2020.
} 
regra, as tonalidades com sustenidos são as preferidas do músico popular gaúcho (BANGEL,1989). Para facilitar a análise, a audição da toada "Prenda Minha"11, pode ser interessante.

Os compassos binários e ternários predominam nos gêneros musicais gaúchos, principalmente o 2/4, o 2/2 e o 3/4. No entanto, muitas vezes há deslocamentos de acentuações, de acordo com a música propriamente dita. É o que ocorre, por exemplo, com o chamamê. Ao ser executado no acordeão, este possui uma "puxada" de fole, do $2^{\circ}$ para o $3^{\circ}$ tempo, ocorrendo uma acentuação no $3^{\circ}$ tempo do compasso, ao invés do $1^{\circ}$. Aí, portanto, há uma diferenciação do chamamê para a rancheira. Para que se possa fazer uma ideia, o acompanhamento da "baixaria"12 no chamamê, em um compasso 3/4, é de três semínimas, com uma acentuação na última semínima. $\mathrm{Na}$ rancheira, também com as três semínimas, diferencia-se pela acentuação, que é na primeira.

A forma musical é outro aspecto interessante a ser analisado na música gaúcha, que tem uma predominância na forma binária, na maioria das composições. Nesta forma, o esquema formal apresentado é A-B, sendo que a primeira parte ou frase é a principal - a pergunta -, e a segunda, secundaria. Essas partes são, portanto, contrastantes, tanto rítmica quanto melodicamente. Em um número menor, as músicas na forma musical ternária também aparecem nos gêneros gaúchos ( $A-B-A)$. $A$ canção "Prenda Minha", por exemplo, está estruturada na forma binária simples. "O $1^{\circ}$ período pergunta e propõe em todas as células e incisos; o $2^{\circ}$ período responde e conclui" (BANGEL, 1989, p. 32).

O timbre da música do RS é bastante peculiar. Os instrumentos musicais que aparecem na maioria das músicas gaúchas, além da voz cantada, são o acordeão, 0 violão e o bombo-leguero. Pode aparecer, também, a rabeca (espécie de violino rústico), fazendo uma melodia mais aguda e um contracanto, também, é bom lembrar que "O assovio e o tilintar de esporas personalizam o timbre gaúcho" (BANGEL,1989, p. $62)$.

${ }^{11}$ Vale apreciar a canção "Prenda Minha", na interpretação do Conjunto Farroupilha. A gravação é do disco Amargo (1953-1956). https://www.youtube.com/watch?v=mu1ZRyEell0.

${ }^{12}$ Modo como alguns músicos gaúchos denominam o acompanhamento no acordeão.

WOLFFENBÜTTEL, Cristina Rolim. Música no Rio Grande do Sul: conhecendo as origens e alguns gêneros musicais. Revista da FUNDARTE. Montenegro, p.254-277, ano 20, № 40, janeiro/março de 2020. Disponível em: http://.seer.fundarte.rs.gov.br/index.php/RevistadaFundarte/index> 31 de março de 2020. 


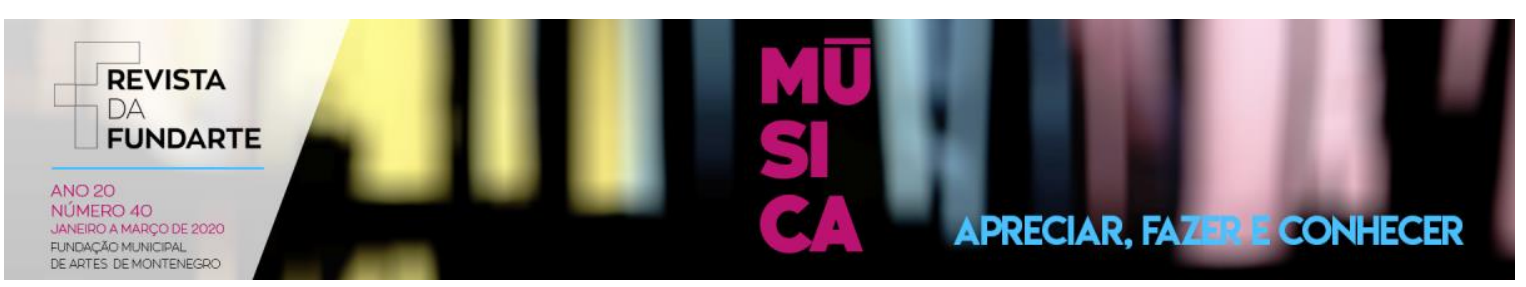

Após o detalhamento das características gerais, predominantes na música do sul do Brasil, pode-se passar a mencionar alguns gêneros musicais mais cultivados no pampa gaúcho: a vaneira, o vaneirão, o bugio e a trova. Logicamente que estes não são os únicos. Contudo, podem ser considerados os primeiros para um ponto de partida, rumo ao conhecimento da música desta região.

\section{Gêneros Musicais do Rio Grande do Sul}

A vaneira, gênero musical proveniente da habanera, fundiu-se com o fandango espanhol, resultando numa música que se pode ouvir frequentemente na região sulina.

A habanera, dança lenta, em compasso 2/4, é originada dos negros de Cuba e Haiti. Esse gênero realizou uma considerável trajetória, antes de chegar no Brasil e, por consequência, no RS. Foi "exportado" para a Espanha e, chegando "ao Brasil, inundou todo o país a partir de 1866" (KIEFER, 1983, p. 18).

O compositor espanhol Sebastián de Yradier (1908 - Alava/1985 - Victoria) foi o autor da célebre habanera "La Paloma", conhecida ainda hoje por muitos, e que tanta popularidade teve no Brasil. A grande aceitação popular dessa obra pode ser exemplificada pelo grande número de partituras impressas de "La Paloma", transcrições para vários instrumentos musicais, etc. Para conhecer ou recordar esta canção que tanto fez sucesso vale escutar na voz de Cascatinha e Inhana ${ }^{13}$.

Fora do Brasil, a popularidade da habanera também ocorreu. Conforme relata Ayestarán (1967, p. 87), o "espanhol Yradier foi o autor da célebre habanera 'La Paloma' de tanta popularidade no México durante o Império de Maximiliano, e do "El Arreglito", que publicou em Madri, em 1840, e que Bizet tomou mais tarde textualmente para sua célebre habanera da opera "Carmen", crendo-a de origem popular e anônimo espanhol". Slonimsky (1945, p. 180) complementa explicando que a "habanera é

13 Cascatinha e Inhana foi uma dupla sertaneja brasileira formada pelo casal Francisco dos Santos, chamado Cascatinha (1919-1996) e Ana Eufrosina da Silva Santos, conhecida como Inhana (1923-1981). Foi uma das duplas de maior sucesso da música sertaneja brasileira, pioneira em trazer a influência da música latina para o gênero. Canção "La Paloma", gravada por Cascatinha e Inhana, em 1951. https://www.youtube.com/watch?v=nwdleNoUvQU.

WOLFFENBÜTTEL, Cristina Rolim. Música no Rio Grande do Sul: conhecendo as origens e alguns gêneros musicais. Revista da FUNDARTE. Montenegro, p.254-277, ano 20, no 40, janeiro/março de 2020. Disponível em: http://.seer.fundarte.rs.gov.br/index.php/RevistadaFundarte/index> 31 de março de 2020. 
caracterizada por um inconfundível balanço rítmico 2/4 que é também a fórmula do Tango Argentino".

Ao chegar ao Brasil e, principalmente, nos ranchos do $\mathrm{RS}$, a habanera transformou-se em "havanera", "havaneira" e, mais tarde, "vaneira". Com essa transformação da própria palavra, o gênero também foi sofrendo diversas influências, passando por um processo de aculturação com outros gêneros musicais. Dessas influências, podem ser constatadas algumas características da polca europeia resultando, até, o surgimento de músicas com denominações de "polca-havaneira" ou "polca-habanera".

Dentre as características musicais propriamente ditas, a vaneira pode apresentar acompanhamentos rítmicos básicos, tais como:

a) colcheia pontuada / semicolcheia / colcheia / colcheia

b) colcheia pontuada/semicolcheia ligada à colcheia/colcheia

c) colcheia/semicolcheia/semicolcheia/colcheia/colcheia

O compasso, como se pode perceber, é o binário simples (2/4).

A forma musical predominante é a binária, com o seguinte esquema formal: A-AB-B. Podem aparecer algumas variantes deste esquema. As frases melódicas geralmente são curtas e espaçadas apresentando, via de regra, pausas antes do aparecimento de outra frase, ou mesmo da repetição da mesma. O período é binário (com 2, 4 ou 8 compassos).

O andamento é mais moderado, podendo apresentar inícios anacrústicos. A harmonia guarda as características mencionadas na caracterização da música sul-riograndense, ou seja, estrutura-se dentro das funções de tônica e dominante (eventualmente, Subdominante), e utiliza os modos Maiores (mais raramente o menor), apresentando as escalas naturais, com casuais alterações. Os instrumentos que integram os conjuntos instrumentais para executar as vaneiras gaúchas apresentam a gaita e o violão. Algumas vezes o bombo-leguero também compõe o grupo instrumental. Pelas razões citadas anteriormente, na atualidade esta sonoridade tem 
sofrido transformações. Um bom exemplo é a "Vaneira Grossa", interpretada pelo grupo Os Monarcas ${ }^{14}$.

O vaneirão, descendendo diretamente da vaneira e, por consequência, da habanera, apresenta-se com as mesmas características da vaneira diferindo, porém, no que diz respeito às frases melódicas, as quais, no vaneirão, se estruturam com a união das frases através de ornamentações. Além disto, o andamento é mais acelerado que o da vaneira, fazendo com que o caráter desta música seja mais alegre, incentivando à dança.

Muitos músicos gaúchos denominam o vaneirão com a alcunha de "limpabanco", dados os traços festivos e empolgantes da música, constituindo-se num convite a "bailar". Assim, ninguém consegue ficar sentado no baile; todos se sentem contagiados pela música, ficando "limpos" os bancos. Limpa-banco é uma música que contagia as pessoas para irem dançar no salão; antigamente, o limpa-banco era a polca, agora é o vaneirão. Bertussi (2014), ao abordar sobre o limpa-banco, explica que não era especificamente um tipo de música, tampouco um gênero musical em particular, "mas uma expressão para pedir ao gaiteiro uma música que ele sabia que o povo gostava de dançar, deixando os bancos da sala limpos. Não ficava ninguém sentado" (p. 70).

O acompanhamento rítmico presente é semelhante ao da vaneira, ou seja, em compasso 2/4: colcheia pontuada/colcheia/colcheia. Em aspectos gerais, o que permite diferenciar um vaneirão de uma vaneira é o seu andamento. O vaneirão é mais rápido, e suas frases musicais são, também, mais movidas, normalmente com o uso de semicolcheias ${ }^{15}$.

Um dos elementos mais interessantes apresentados pelos gaúchos é a tendência à descritividade, sendo uma tentativa do habitante do sul de fazer uma extensão, na música, do seu ambiente, resultando o aparecimento de diversas denominações de caracterização musical; com o vaneirão ocorre o mesmo. É o caso

14 Os Monarcas é o nome do conjunto musical regionalista do RS, com muita aceitação popular. https://www.youtube.com/watch?v=E709SV06LrE.

WOLFFENBÜTTEL, Cristina Rolim. Música no Rio Grande do Sul: conhecendo as origens e alguns gêneros musicais. Revista da FUNDARTE. Montenegro, p.254-277, ano 20, no 40, janeiro/março de 2020. Disponível em: http://.seer.fundarte.rs.gov.br/index.php/RevistadaFundarte/index> 31 de março de 2020. 


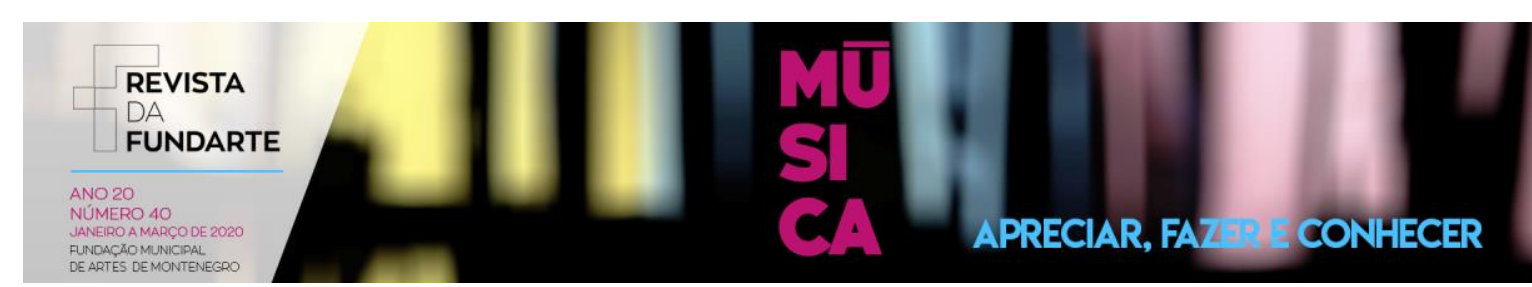

dos nomes como "Vaneira Grossa", "Vaneirinha", "Vaneirão Missioneiro", "Bugio Assanhado", "Bugio Burrinho", entre outros. Uma apreciação pode ser feita com a escuta do "Bugio Assanhado", na interpretação excelente do memorável acordeonista Adelar Bertussi' ${ }^{16}$. Adelar destacou-se no cenário musical, juntamente com seu irmão, Honeyde, pela virtuosidade ao executar o acordeão.

O bugio, outro gênero musical muito conhecido no RS, tem antecedentes controversos até a atualidade, sendo reconhecido pelos músicos do sul como a única música realmente de origem gaúcha.

Quanto ao seu surgimento, há hipóteses que são apontadas nas conversas dos gaiteiros da região; no entanto, existe uma certa unanimidade quando se fala que a inspiração para a criação do gênero foi, realmente, o macaco bugio, animal que, até pouco tempo, habitava em abundância as matas naturais do RS. Explicam os músicos que o "ronco" da gaita, elemento característico da música, é uma imitação do som produzido pelo animal.

Em pesquisas históricas realizadas sobre o assunto, Lamberty (1992) explica que o surgimento do gênero musical bugio está ligado à figura de Wenceslau da Silva Gomes, mais conhecido por "Neneca Gomes", um gaiteiro da cidade de São Francisco de Assis, RS. De acordo com suas averiguações entre os músicos da localidade, contase que este gaiteiro teria inventado o gênero bugio, quando ficava deitado, à sombra das árvores nativas, com a gaita sobre o peito, observando os bugios que cantavam nos galhos ao alto. Neneca executava um vaneirão, e respondia com os baixos do acordeão, procurando imitar o ronco do macaco bugio (LAMBERTY, 1992). Assim, de tanto tentar imitar, criou um bugio, o chamado "Os Três Bugios", homenageando os três macacos bugios que possuía.

Por volta de 1930, aproximadamente, a nova música foi se espalhando por toda a parte. No entanto, o conhecimento só veio a ser concretizado quando em 1936, o então jovem gaiteiro Antonio Soares de Oliveira, mais conhecido como "Tio Bilia",

15 Um escuta ilustrativa do vaneirão pode ser feita acessando o link https://www.youtube.com/watch?v=COKpS1K6Upl. É o "Vaneirão Lascado", na interpretação de "Os Serranos", grupo criado em 1969, em Bom Jesus/RS, cujas atividades persistem até a atualidade. WOLFFENBÜTTEL, Cristina Rolim. Música no Rio Grande do Sul: conhecendo as origens e alguns gêneros musicais. Revista da FUNDARTE. Montenegro, p.254-277, ano 20, n 40, janeiro/março de 2020. Disponível em: http://.seer.fundarte.rs.gov.br/index.php/RevistadaFundarte/index> 31 de março de 2020. 
tomou conhecimento do bugio, passando a executá-lo em sua gaita. Mais tarde, em 1955, os “Irmãos Bertussi" gravaram o primeiro bugio, o "Casamento da Doralice"17.

Há, no entanto, outra "corrente teórica" que afirma ser a região de São Francisco de Paula a que originou o novo "som da campanha".

Não importa, na verdade, para as finalidades propostas neste trabalho, o verdadeiro lugar no qual surgiu o bugio. É relevante, isto sim, conhecer as características musicais presentes neste gênero.

No tocante aos aspectos técnico-musicais, o bugio possui o compasso binário simples, desenvolvendo um ritmo semelhante ao da vaneira. O acompanhamento tenta traduzir, de certa maneira, o modo de caminhar ao macaco, espécie de "chocalhada", sacudida. Este "requebro" se efetiva, musicalmente, através de uma "sacudida" do fole do acordeão, na segunda metade do $1^{\circ}$ tempo do compasso.

Existe outra característica muito importante na melodia do bugio, quando desenvolve um desenho de "pergunta e resposta", assemelhando-se à "conversalhada" do bicho. Isto ocorre devido às repetições das semicolcheias, apresentadas no início da música.

Segundo o músico gaúcho Tasso Bangel (1989, p. 37), "o bugio tem sua raiz no lundu e no maxixe, devido a sua métrica e a seu acento no primeiro tempo".

A trova é um gênero poético-musical muito difundido entre os "cantadores" populares que, muitas vezes, denominam-na "trova em desafio". Constituem-se numa modalidade de canto bastante difícil de ser executada, na medida em que os versos são improvisados, espontâneos, feitos no momento do desafio e sendo, portanto, fundamental a rapidez de raciocínio, por parte dos trovadores ${ }^{18}$.

Conforme Garcia (1990), há muitos e marcantes traços europeus nas trovas gaúchas, principalmente vindas a partir de Portugal. Essas influências, de acordo com a autora, também são percebidas em outras regiões do Brasil. Para Garcia (1990):

\footnotetext{
${ }^{16}$ Adelar Bertussi interpreta "Bugio Assanhado" no Encontro internacional de gaiteiros em Curitiba/PR. https://www.youtube.com/watch?v=2w2Juq2u7n4.

17 Os Irmãos Bertussi interpretam o "Casamento da Doralice", no disco Coração Gaúcho, selo Copacabana. https://www.youtube.com/watch?v=4xu4XSweObg\&t=22s.

18 O exemplo de trova apresentado ocorreu entre o paulista Flor da Serra e o gaúcho Gildo de Freitas, um dos ícones da música no RS. https://www.youtube.com/watch?v=FECpgpVxaqk.

WOLFFENBÜTTEL, Cristina Rolim. Música no Rio Grande do Sul: conhecendo as origens e alguns gêneros musicais. Revista da FUNDARTE. Montenegro, p.254-277, ano 20, no 40, janeiro/março de 2020. Disponível em: http://.seer.fundarte.rs.gov.br/index.php/RevistadaFundarte/index> 31 de março de 2020.
} 


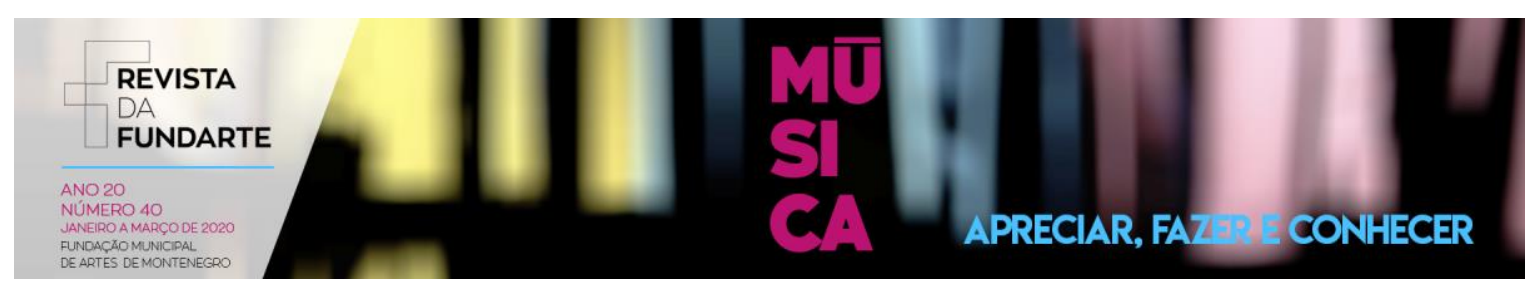

Os cantadores populares são tão vigentes hoje no Rio Grande do Sul como o foram no passado na Europa, os "trouvéres" franceses e o "minnesingers" alemães. Na espontaneidade que lhes é peculiar, qualquer ambiente é propício à sua cantoria: rodeios, bailes, festivais, carreiras, festas em casa de amigos, reuniões familiares, bares, bolichos, galpões, ramadas e até mesmo durante a festa do Carnaval, cantam em tendinhas. Seu público simples, é sempre interessado, nunca se afastando antes do término do desempenho do cantador, entusiasmado, aplaudindo, incentivando o artista. (GARCIA, 1990, p. 67).

Bangel (1989) explica que são constatados aspectos muito interessantes da historicidade desta música. Conforme o autor, a "[...] trova é uma forma melódica acompanhada (homofônica), com tradição de canto libertário desde os trovadores medievais, quando começou a música vocal-instrumental profana" (BANGEL, 1989, p. $35)$.

No Brasil este gênero de cantoria aparece em diversas localidades. No nordeste, por exemplo, podem ser verificadas várias modalidades, algumas já em desuso, como a quadra, a colcheia, a carretilha, etc, e outras ainda são cantadas, tendo em vista o desafio.

É necessário esclarecer, a fim de diferenciar a trova do repente. A trova tem um caráter de desafio, ou seja, há uma disputa, resultando um vencedor e perdedores. No repente não existe esta característica; o repentista cria versos e estrofes sobre um determinado assunto, sem desafiar outro cantador. Ele entoa sozinho.

A trova gaúcha, um dos importantes gêneros da música sul-rio-grandense, constituindo-se uma forma melódica acompanhada, muitas vezes pelo acordeão, e que possui suas origens no canto libertário, desde os trovadores da Idade Média, com o advento da música vocal-instrumental popular, sendo uma espécie de reação ao contraponto erudito eclesiástico (BANGEL, 1989). Dentre as mais conhecidas ou, talvez, mais praticadas, encontram-se as trovas em Mi Maior de Gavetão, Martelo e por Milonga ${ }^{19}$.

19 Tem-se o conhecimento do surgimento de outros tipos de trova no RS, como a de Pilão, entre outras. Porém, neste estudo, não se fará alusão a elas, justamente pelo fato de não se possuir, até o momento, pesquisas mais consistentes e, portanto, seguras, para realizar a análise. Optou-se, aqui, por expor as trovas que, efetivamente, podem ser analisadas.

WOLFFENBÜTTEL, Cristina Rolim. Música no Rio Grande do Sul: conhecendo as origens e alguns gêneros musicais. Revista da FUNDARTE. Montenegro, p.254-277, ano 20, no 40, janeiro/março de 2020. Disponível em: http://.seer.fundarte.rs.gov.br/index.php/RevistadaFundarte/index> 31 de março de 2020. 


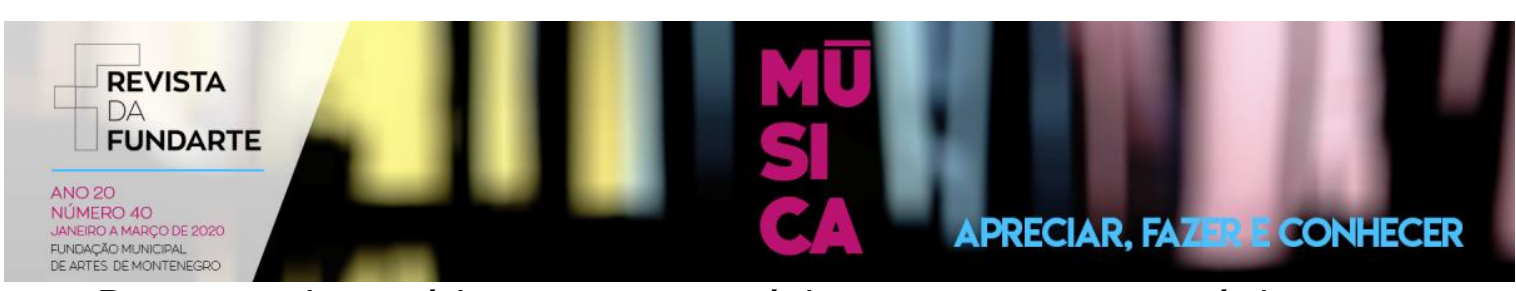

De um modo genérico, as trovas gaúchas possuem características comuns umas às outras. Iniciam com uma introdução musical, a qual serve para preparar a trova e oferecer uma maior familiarização do trovador com o tom da música sobre o qual desenvolverá sua trova. Após esta introdução, o primeiro trovador inicia a trova, realizando a primeira estrofe. Essa estrofe possui seis versos, cuja estrutura caracteriza-se pela rima do $2^{\circ}$ verso com o $4^{\circ}$ e o 6․․ Os versos de número 1, 3 e 5 não rimam com outros, apresentando terminações de palavras diferentes. A primeira estrofe fica da seguinte maneira, quanto às rimas:

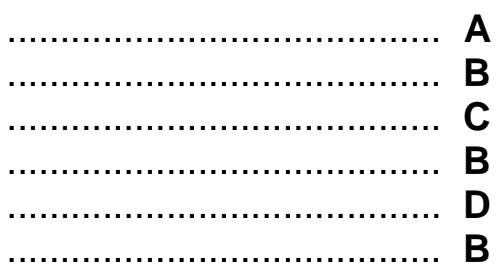

A trova em Mi Maior de Gavetão possui particularidades. O nome Mi Maior de Gavetão, segundo depoimentos de alguns trovadores, advém da tonalidade que é a mais utilizada na execução do acordeão, o Mi Maior (GARCIA, 1993, 1990). Ainda que façam a transposição para outros tons, continuam a dizer que estão tocando o Mi Maior de Gavetão em sol, ré, etc. A denominação "gavetão" está associada, para muitos, ao acorde arpejado inicial de Mi Maior, com o qual iniciam a execução instrumental. Outros referem como sendo uma posição da mão que executa o acompanhamento na no acordeão: a posição de gavetão. Conforme Garcia (1993), a palavra gavetão é utilizada pelos acordeonistas, indicando o acorde arpejado com o qual a trova inicia ${ }^{20}$.

Em termos de gênero musical, o "Mi Maior de Gavetão" tanto pode ser um xote em compasso quaternário, ou uma polca em compasso binário aparecendo, também, sob outras espécies. Com a mesma estrutura da letra do "gavetão", o cantador gaúcho ainda trova em ritmo de valsa ou vaneira. Todas as tonalidades são maiores. Assim, depreende-se que o gênero musical está na dependência das possibilidades e escolha

20 Um exemplo de trova em Mi Maior de Gavetão pode ser apreciado neste link https://www.youtube.com/watch?v=VwZMLGmLSRs .

WOLFFENBÜTTEL, Cristina Rolim. Música no Rio Grande do Sul: conhecendo as origens e alguns gêneros musicais. Revista da FUNDARTE. Montenegro, p.254-277, ano 20, no 40, janeiro/março de 2020. Disponível em: http://.seer.fundarte.rs.gov.br/index.php/RevistadaFundarte/index> 31 de março de 2020. 


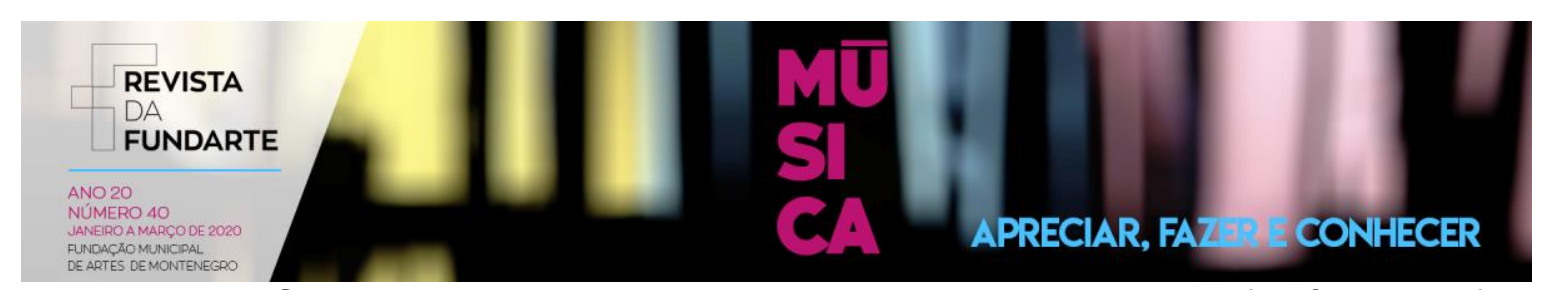

dos gaiteiros. O andamento costuma ser moderado e bastante flexível, conforme a solicitação dos trovadores (GARCIA, 1990).

É formada de estrofes em sextilha, tendo versos heptassilábicos. As rimas guardam as características mencionadas anteriormente, ou seja, rimas no $2^{\circ}$, 4ํㅡ e $6^{\circ}$ versos. O compasso é sempre quaternário, e cada estrofe corresponde a 12 compassos. O andamento é lento, tendo a melodia repetida nas estrofes, com a possibilidade de variantes. Conforme pesquisas, é possível que este tipo de trova tenha sido originada de uma mistura entre gêneros musicais como o xote e a toada (GARCIA, 1993). Garcia (1993) oportuniza o conhecimento de um exemplo de trova em Mi Maior de Gavetão, sendo um desafio entre dois trovadores com os quais realizou pesquisa em anos anteriores, os quais ficaram conhecidos como Evangelista e Tazinho. Conforme os registros da pesquisadora, alguns versos da trova eram os seguintes:

\section{Evangelista}

Eu volto de novamente

E cantando bem debochado.

É um caro amigo que eu tenho

Que mora do outro lado.

Te agarra com as tuas unhas

Porque é laço dos dois lado(s).

Interlúdio Musical

Tazinho

Porque é laço dos dois lado(s)

E eu sou galo competente.

Eu sou lá de São Luis

Quero bem a toda a gente.

Mas você é galo veio

Que já perdeu até os dente(s).

Interlúdio Musical

\section{Evangelista}

Quem já perdeu até os dente(s)?

Mas é galo bem charrua.

Tu sabe(s) que eu canto bem.

Minha carne é muito crua.

P'ra você não quero os dente(s)

Que hoje eu te quebro a pua.

e, assim, por diante...

WOLFFENBÜTTEL, Cristina Rolim. Música no Rio Grande do Sul: conhecendo as origens e alguns gêneros musicais. Revista da FUNDARTE. Montenegro, p.254-277, ano 20, № 40, janeiro/março de 2020. Disponível em: http://.seer.fundarte.rs.gov.br/index.php/RevistadaFundarte/index> 31 de março de 2020. 


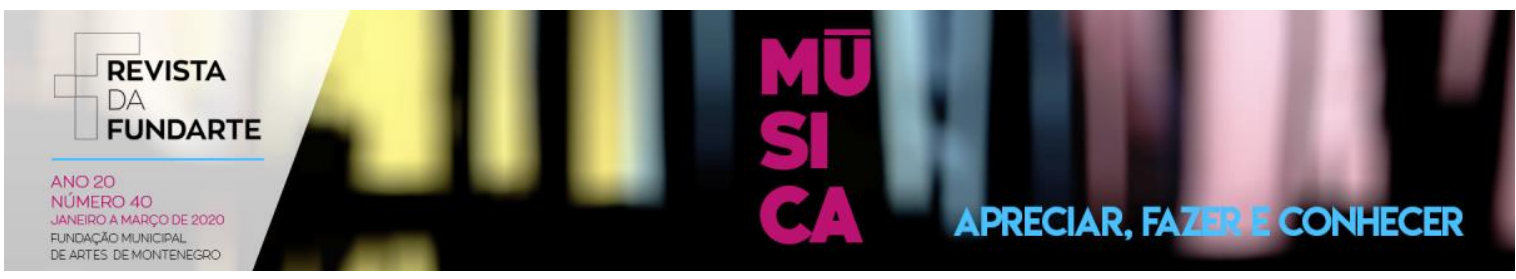

Um aspecto a ser tratado, também, é a característica que a trova apresenta em sua finalização. Como se pode observar, o último verso de cada trovador (6ำ verso) é sempre repetido pelo trovador seguinte, tornando-se seu primeiro verso. Nos excertos apresentados anteriormente, por exemplo, foram: "Porque é laço dos dois lado(s)", do trovador Evangelista; "Que já perdeu até os dente(s), do trovador Tazinho". Sintetizando, a estrutura básica da trova em Mi Maior de Gavetão, é:

Quadro 1: Síntese da Trova em Mi maior de Gavetão

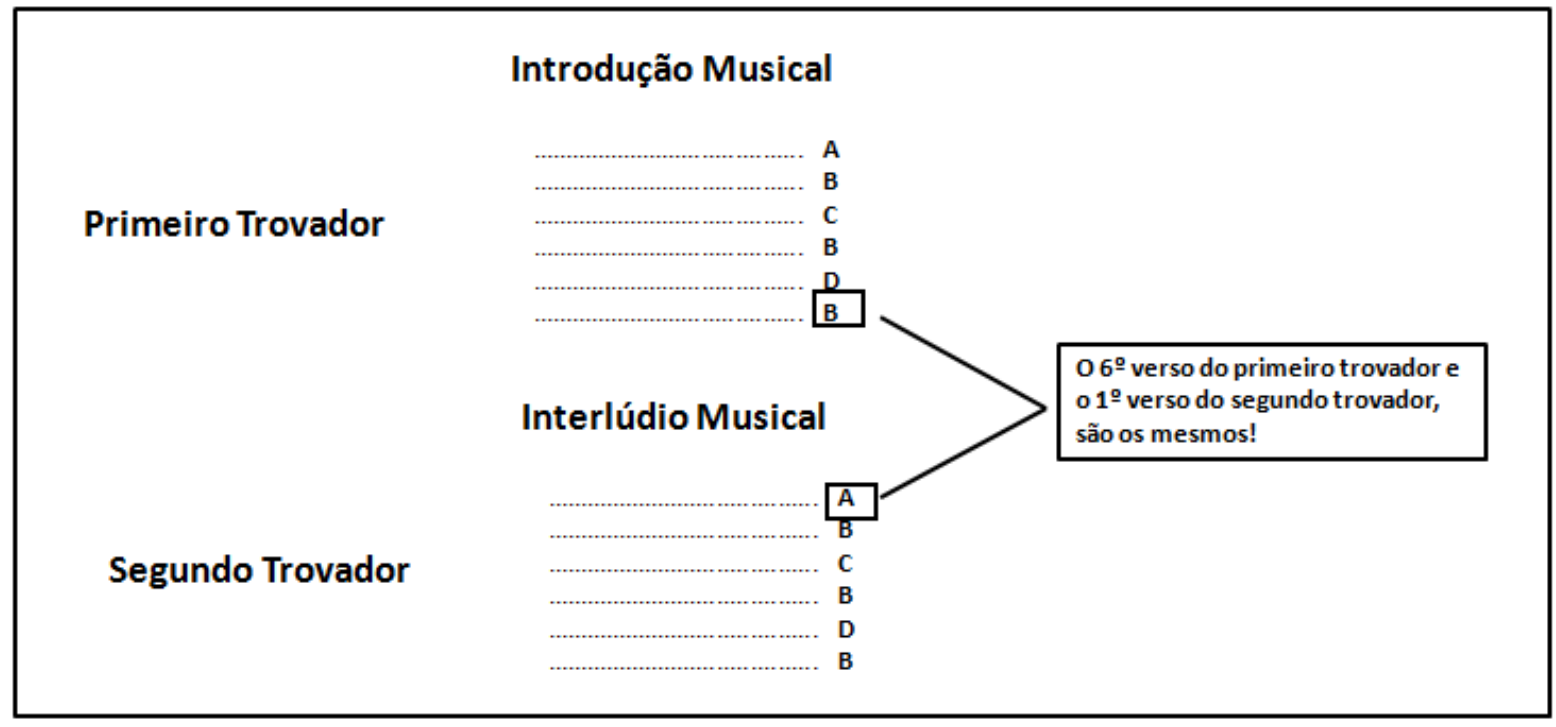

Fonte: Elaborado pela autora.

Estas características, como citado anteriormente, repetem-se em todas as trovas gaúchas. No entanto, o que permitirá discriminar umas das outras é, justamente, a maneira pela qual o restante das características de cada desafio irá se desenvolver.

Outra trova muito praticada no RS é a Trova de Martelo. Possuindo, basicamente, as mesmas características da trova em Mi Maior de Gavetão, essa modalidade de desafio é mais difícil de ser realizada, na medida em que requer uma maior rapidez de raciocínio, exigindo respostas imediatas. A razão dessa rapidez de pensamento está fundamentada na própria estrutura desta trova.

Contrariamente à trova em Mi Maior de Gavetão, a de Martelo não possui um interlúdio musical, resultando na falta do tempo para o trovador "pensar" na resposta que irá dar ao seu adversário. Além disso, o primeiro trovador não conclui seu WOLFFENBÜTTEL, Cristina Rolim. Música no Rio Grande do Sul: conhecendo as origens e alguns gêneros musicais. Revista da FUNDARTE. Montenegro, p.254-277, ano 20, no 40, janeiro/março de 2020. Disponível em: http://.seer.fundarte.rs.gov.br/index.php/RevistadaFundarte/index> 31 de março de 2020. 


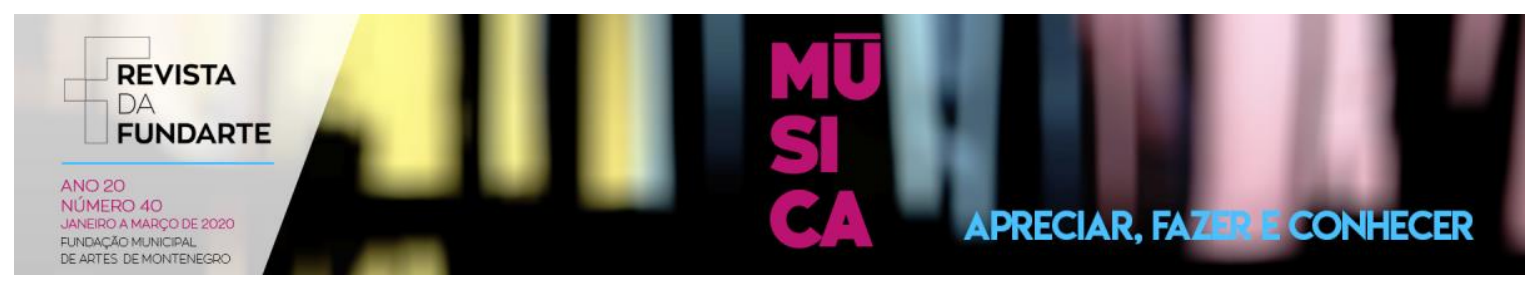

pensamento na sua primeira estrofe, ficando esta tarefa para o outro trovador. Isso ocorre sempre assim. Nenhum trovador conclui o seu pensamento ${ }^{21}$. Eis um quadro que sintetiza a estrutura básica da trova de Martelo:

Quadro 2: Síntese da Trova de Martelo

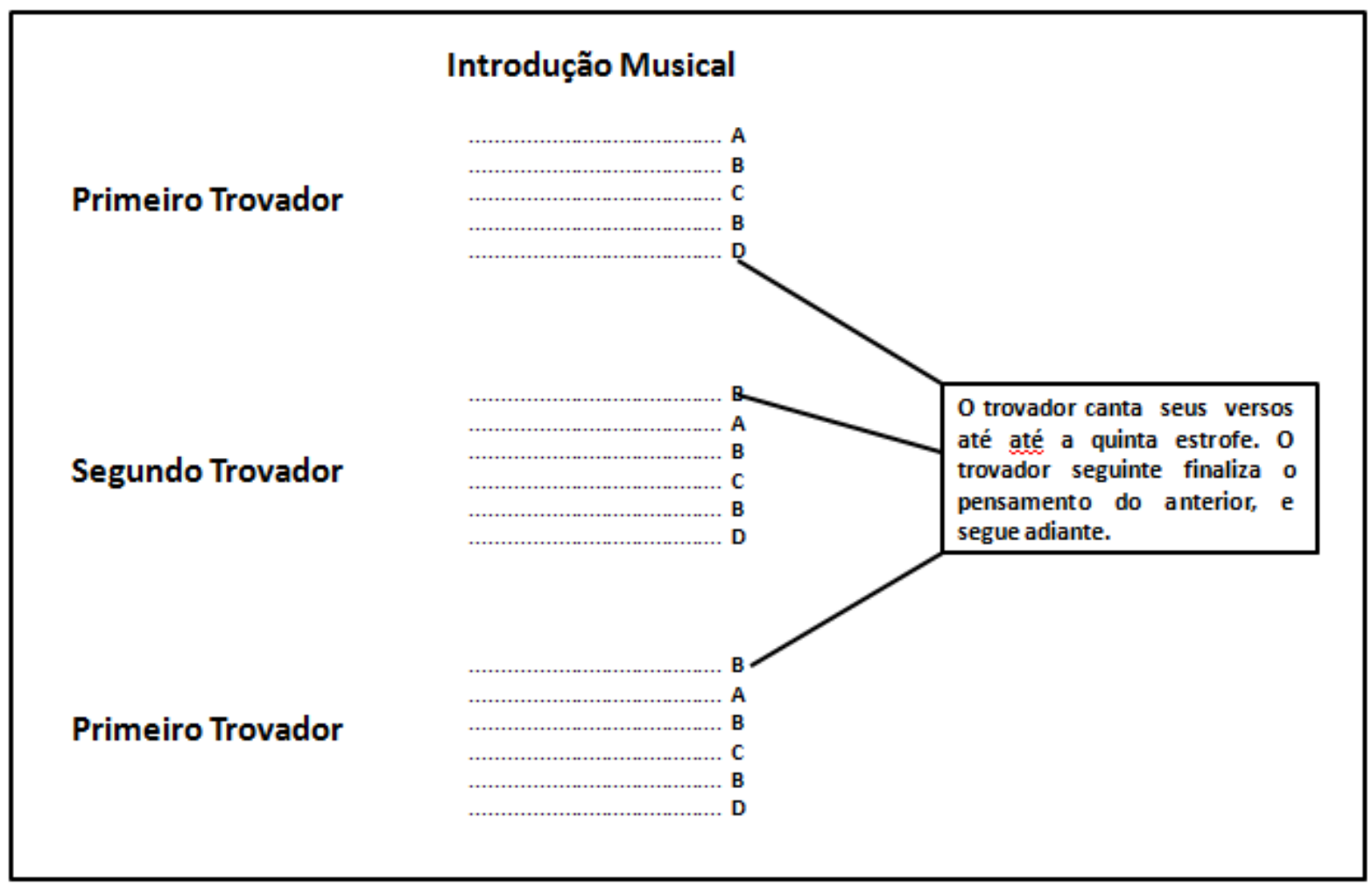

Fonte: Elaborado pela autora.

Exceto por estas características particulares a esta trova, o restante continua da mesma forma como ocorre no Mi Maior de Gavetão. As tonalidades são maiores, as músicas, as mesmas, os andamentos mais lentos.

Por fim, resta tratar da Trova por Milonga. Neste desafio, as características da trova em Mi Maior de Gavetão conservam-se em muitos aspectos. A diferença está centrada, basicamente, na música, bem como na tonalidade, na qual predominam os tons com modos menores. Os componentes musicais e estruturais deste tipo de trova, à semelhança do Martelo, são os mesmos que os da em Mi Maior de Gavetão. A

${ }^{21}$ O exemplo de Trova de Martelo aqui apresentado ocorre entre a trovadora Tetê Carvalho e Volmir Martins, e enocntra-se no link https://www.youtube.com/watch?v=ao6WHNrOY4I.

WOLFFENBÜTTEL, Cristina Rolim. Música no Rio Grande do Sul: conhecendo as origens e alguns gêneros musicais. Revista da FUNDARTE. Montenegro, p.254-277, ano 20, no 40, janeiro/março de 2020. Disponível em: http://.seer.fundarte.rs.gov.br/index.php/RevistadaFundarte/index> 31 de março de 2020. 
diferença está, basicamente, centrada na música, bem como a tonalidade. A música utilizada para esta trova é a milonga, e as tonalidades são as menores.

\section{Considerações Finais}

Este artigo objetivou apresentar um panorama da música no Rio Grande do Sul. Com certeza, está longe de ser uma palavra final ou a referência sobre o assunto, tampouco esta é uma pretensão. Contudo, objetivou reacender a chama do interesse pelas pesquisas em torno da riqueza do que se apresenta nas terras pampeanas, principalmente quanto à sua música.

Entende-se, ao finalizar a exposição aqui apresentada, que não se pode dizer que a cultura e a música sul-rio-grandense é de um ou de outro modo, mas é justamente uma miríade de possibilidades, posto que as terras gaúchas receberam, e ainda tem recebido um grande contingente de pessoas que, praticamente no cotidiano, acorrem a este Estado, em busca da construção de uma vida.

Portanto, a diversidade que constitui a cultura e a música no Estado é vasta, e necessita ser mais e melhor conhecida. Espera-se, nesse sentido, contribuir um pouco com o despertar desse conhecimento.

\section{Referências:}

ANDRADE, Mário. Danças dramáticas do Brasil. 3 vols., 2ª̣ed. Belo Horizonte, Itatiaia / INL, 1982.

AYESTARÁN, Lauro. El folklore musical uruguayo. Montevideo: Arca, 1967.

BANGEL, Tasso. O estilo gaúcho na música brasileira. Porto Alegre: Martins Livreiro, 1989.

BERTUSSI, Honeyde. Músicas, festas e bailes. Porto Alegre: EDIGAL, EDUCS, 2014.

CASCUDO, Luis da Câmara. Dicionário do folclore brasileiro. Belo Horizonte: Itatiaia, 5ª ed., 1984.

COSTA, Rovílio, BATISTEL, Arlindo I. Assim vivem os italianos. Porto Alegre: EST/EDUCS, 1983. 


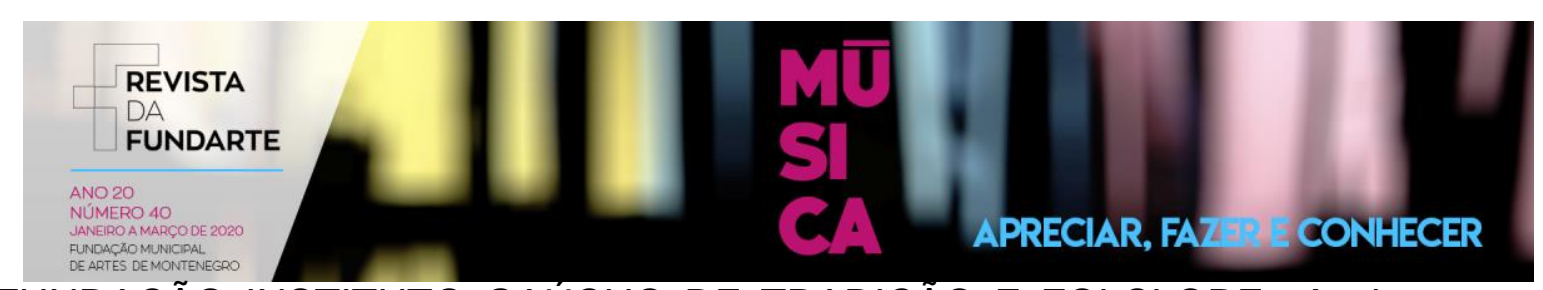

FUNDAÇÃO INSTITUTO GAÚCHO DE TRADIÇÃO E FOLCLORE. Assim cantam os gaúchos. Porto Alegre: IGTF, 1984.

GARCIA, Rose Marie Reis. Chansons des trovadores du Rio Grande do Sul - Bresil: contribuition à l'étude Du chant improvise et du chant narratif. Universitê Lumiere - Lyon 2 - Faculté de lettres, Sciences Du language et des Arts, 1993.

GARCIA, Rose Marie Reis. A trova e décima no Rio Grande do Sul. Porto Arte, Porto Alegre, v. 1, n. 1, 1990, p. 66-82.

KIEFER, Bruno. Música e dança popular: sua influência na música erudita. Porto Alegre: Movimento, 1983.

LAMBERTY, Salvador Ferrando. Abc do tradicionalismo gaúcho. Porto Alegre: Martins Livreiro, 4를. ed., 1992.

LAYTANO, Dante de. O linguajar do gaúcho brasileiro. Porto Alegre: Escola Superior de Teologia São Lourenço de Brindes. Coleção Temas Gaúchos, 1981.

MARQUES, Lilian Argentina Braga. Rio Grande do Sul: aspectos do folclore. Porto Alegre: Martins Livreiro, 1989.

MARCONDES, Marco Antonio. Enciclopédia da música brasileira : erudita folclórica popular. São Paulo: Art Ed., 1977.

NUNES, Zeno Cardoso, NUNES, Rui Cardoso. Dicionário de regionalismos do Rio Grande do Sul. Porto Alegre: Martins Livreiro, 5aㅡ ed., 1993.

SLONIMSKY, N. Music of latin america. New York: Thomas Y. Crowell Company, 1945. 